Jurnal Akuakultur Sungai dan Danau Vol. 4 No. 1 Tahun 2019 Hal. 21 - 27

ISSN Print 2503-4766

ISSN Online 2597-8837

\title{
OPTIMALISASI SUHU TERHADAP DAYATETAS (Hatching rate) TELUR IKAN KOMET (Carassius auratus)
}

\author{
Edi Candra \\ Alumni Program Studi Budidaya Perairan, Fakultas Pertanian Universitas Batanghari \\ Jl. Slamet Riyadi, Broni Jambi, 36122. Telp. +6074160103 \\ Email korespondensi : edicandra01@gmail.com
}

\begin{abstract}
Comet fish is one type of ornamental fish that has been widely cultivated because it has an attractive body shape and color. The main obstacle in the development of comet fish farming is the limited number of seeds, both in quality and quantity. Egg quality is a major factor in the success of fish hatcheries. According to Andriyanto et al, (2013) quality eggs have a high level of fertilization and hatching (high fertility and hatching rate). Putri et al. (2013) stated that water quality factors, especially temperature, were very important factors in the life of the organism. The study was conducted for 1 month which was implemented April to May 2018. The place of research was carried out at the UPR (Rakyak hatchery unit). big. environmental design Completely Randomized Design (CRD) with 4 (four) treatments and 3 (three) replications, each treatment is: Treatment A: Temperature $26 o C+$ Eggs 100 grains, Treatment B: Temperature $28 o C+$ Eggs 100 grains, Treatment C: Temperature $30 \mathrm{oC}+$ Egg 100 grains, Treatment D: Temperature $320 \mathrm{C}+$ Eggs 100 grains. The parameters observed were: Egg hatchability and water quality. The results obtained for the best temperature treatment were treatment $B$ with a temperature treatment of $280 C$ with hatchability of $73.33 \%$.
\end{abstract}

Keywords : optimal temperature, hatching rate, komet fish

Ikan komet merupakan salah satu jenis ikan hias yang telah banyak dibudidayakan karena memiliki bentuk tubuh serta warna yang menarik.Kendala utama dalam pengembangan budidaya ikan komet adalah terbatasnya benih, baik dalam kualitas maupun kuantitasnya.Kualitas telur merupakan faktor utama keberhasilan dalam pembenihan ikan. Menurut Andriyanto et al, (2013) telur yang berkualitas memiliki tingkat pembuahan dan penetasan yang tinggi (fertilitas dan hatching rate tinggi). Putri et al, (2013) menyatakan bahwa faktor kualitas air terutama suhu merupakan faktor yang sangat penting dalam kehidupan organisme, Penelitian ini dilaksanakan selama 1 bulan yang telah dilaksanakan april sampai dengan bulan mei 2018. Tempat penelitian dilaksanakan di UPR (unit pembenihan rakyak) kenali besar.rancangan lingkungan Rancangan Acak Lengkap (RAL) dengan 4 (empat) perlakuan dan 3 (tiga) ulangan, masing-masing perlakuan tersebut adalah :Perlakuan A : Suhu $26^{\circ} \mathrm{C}+$ Telur 100 butir, Perlakuan B : Suhu $28^{\circ} \mathrm{C}+$ Telur 100 butir, Perlakuan C : Suhu $30^{\circ} \mathrm{C}+$ Telur 100 butir, Perlakuan D : Suhu $32^{\circ} \mathrm{C}+$ Telur 100 butir. Parameter yang diamati adalah : Daya tetas telur dan kualitas air. Hasil penelitian yang diperoleh untuk perlakuan suhu yang terbaik adalah perlakuan B dengan perlakuan suhu $28^{\circ} \mathrm{C}$ dengan daya tetas sebesar $73,33 \%$.

Kata kunci : suhu optimal, daya tetas, ikan komet 


\section{PENDAHULUAN}

Budidaya ikan hias air tawar ternyata mampu memberikan kehidupan bagi banyak orang yang menekuninya. Selain orang suka akan keindahan ikan hias ini, banyak pula orang yang menggantungkan hidupnya dari membudidayakan dan memasarkan ikan hias yang jenisnya bermacam-macam. Tidak jarang beberapa petani yang semula menekuni budidaya ikan konsumsi beralih menekuni budidaya ikan hias. Semua itu dilakukan karena peluang usaha dan potensi ekonomis budidaya ikan hias lebih menggiurkan dibandingkan dengan ikan konsumsi, (Septian et al, 2017).

Pembenihan ikan hias mempunyai prospek pasar ekspor dan lokal. Salah satu ikan yang memiliki harga jual tinggi dan permintaan pasar cukup banyak baik lokal maupun ekspor adalah ikan komet (Carassius auratus). Ikan komet merupakan salah satu jenis ikan hias yang telah banyak dibudidayakan karena memiliki bentuk tubuh serta warna yang menarik. Pasaran dan tingkat permintaan ikan komet yang cukup tinggi serta relatif stabil, harus diimbangi dengan usaha budidaya pada kondisi yang terkontrol.

Kendala utama dalam pengembangan budidaya ikan komet adalah terbatasnya benih, baik dalam kualitas maupun kuantitasnya. Keberhasilan budidaya ikan komet sangat tergantung pada teknologi pembenihan dan pemeliharaan larva. Kualitas telur merupakan faktor utama keberhasilan dalam pembenihan ikan. Menurut Andriyanto et al, (2013) telur yang berkualitas memiliki tingkat pembuahan dan penetasan yang tinggi (fertilitas dan hatching rate tinggi). Putri et al, (2013) menyatakan bahwa faktor kualitas air terutama suhu merupakan faktor yang sangat penting dalam kehidupan organisme, perubahan suhu memberikan pengaruh yang sangat kuat terhadap proses fisiologis dan biologis, suhu merupakan faktor lingkungan yang berpengaruh terhadap perkembangan embrio yang nantinya akan menetas. Seperti dinyatakan Wahyuningtias et al, (2015) Suhu menjadi sangat penting dalam gametogenesis untuk keberhasilan dalam proses pemijahan dan daya tetas telur. Haris dalam Fahrurrazi, (2013) menyatakan bahwa kisaran suhu siang dan malam merupakan kelemahan yang sering ditemui dalam pembenihan yang tidak terkontrol. Kenaikan dan penurunan suhu secara mendadak akan menghambat terjadinya penetasan telur.

Berdasarkan urain tersebut diatas perlu kiranya dilakukan penelitian tentang optimalisasi suhu terhadap daya tetas telur ikan komet $(C$.auratus) guna mencari suhu terbaik untuk penetasan telur ikan komet.

Menurut identifikasi Saanin, (1968) mengemukakan bahwa, ikan komet dapat diklasifikasi sebagai berikut :

$\begin{array}{lll}\text { Filum } & : & \text { Chordata } \\ \text { Kelas } & : & \text { Pisces } \\ \text { Subkelas } & : & \text { Teleostei } \\ \text { Ordo } & : & \text { Ostariphisysoidei } \\ \text { Subordo } & : & \text { Cyprinoidea } \\ \text { Famili } & : & \text { Cyprinidae } \\ \text { Genus } & : & \text { Carassius } \\ \text { Spesies } & : & \text { Carassius auratus }\end{array}$




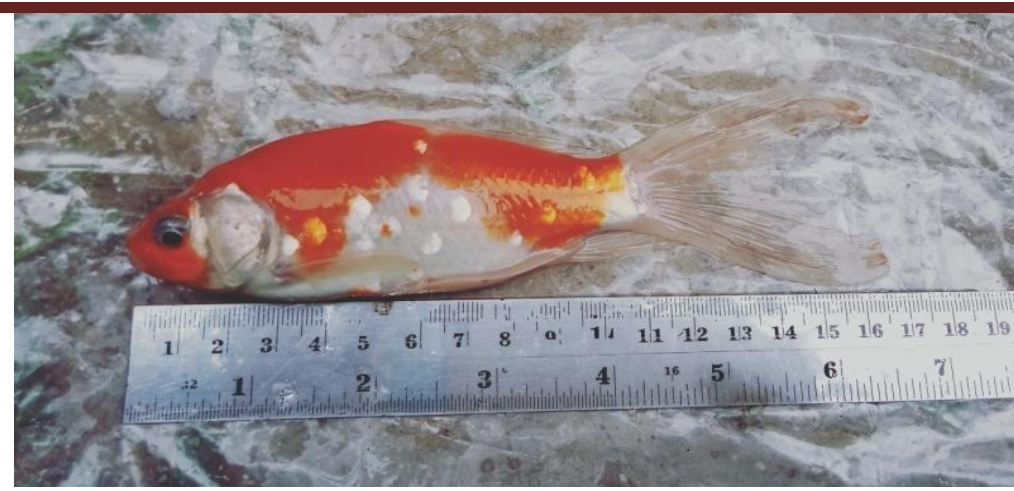

Gambar 1. Morfologi Ikan Komet (C. auratus).

\section{METODOLOGI PENELITIAN}

Penelitian tentang optimalisasi suhu terhadap daya tetas telur ikan komet (C. auratus) dilaksanakan selama 1 bulan yang telah dilaksanakan april sampai dengan bulan mei 2018. Untuk persiapan percobaan dilakukan selama 5 hari, dan pelaksanaan penelitian selama 30 hari. Tempat penelitian dilaksanakan di UPR (Unit Pembenihan Rakyat) Kenali Besar. Adapun alat yang digunakan dalam pelaksanaan penelitian optimalisasi suhu terhadap daya tetas (Hatching Rate) telur ikan komet ( $C$. auratus) antara lain akuarium, mikroskop,saringan, piring, serok halus, aerator, alat tulis, kamera digital, mistar, heater, thermometer, gelas ukur, selang sifon, $\mathrm{pH}$ meter. Sementara untuk bahan yang akan digunakan adalah telur ikan uji yaitu telur ikan komet $(C$. auratus) sebanyak 1.200 butir dari sumber induk yang sama. Penghitungan telur ikan uji dihitung menggunakan volumetri.

Telur ikan komet ( $C$. auratus) yang digunakan berasal dari hasil pemijahan intensif, induk ikan yang digunakan induk yang di pelihara secara intensif di UPR (Unit Pembenihan Rakyat) bagan pete, yang kemudian telur dibawa ketempat penelitian di UPR (Unit Pembenihan Rakyat) Kenali Besar. Wadah yang digunakan dalam pelaksanaan penelitian ini adalah akuarium yang berukuran $60 \times 30 \times 30 \mathrm{~cm}$, sebanyak 12 akuarium sesuai dengan perlakuan yaitu perlakuan A : suhu $26^{\circ} \mathrm{C}$, perlakuan $\mathrm{B}$ : suhu $28^{\circ} \mathrm{C}$, perlakuan $\mathrm{C}$ : suhu $30^{\circ} \mathrm{C}$ dan perlakuan D : suhu $32^{\circ} \mathrm{C}$. Air yang digunakan dalam akuarium berupa air sumur, hal ini bertujuan agar kondisi air dalam akuarium tidak terlalu banyak mengalami perubahan fisika dan kimia, sehingga tidak mempengaruhi kondisi telur.

Tahapan penelitian yang dilakukan dimulai dari persiapan induk, kemudian seleksi induk, induk ikan komet yang digunakan sebanyak 2 pasang dan perbandingan induk jantan dan betina berupa 2-1, yaitu dua jantan dan satu betina. selanjutnya tahap pemijahan. Pemijahan yang dilakukan adalah pemijahan secara buatan. Untuk merangsang induk diperlukan adanya penyuntikan. Penyuntikan yang dilakukan menggunakan ovaprim, dengan dosis $0.03 \mathrm{ml} / \mathrm{kg}$.

Pengaturan suhu menggunakan heater yang ditempatkan dalam masingmasing wadah inkubasi dan diatur sedemikian rupa sehingga didapatkan suhu air media inkubasi yang sesuai dengan perlakuan. Sebelum telur ditebar pada setiap perlakuan terlebih dahulu mempersiapkan subtrat tempat menempelnya telur, yaitu berupa saringan yang berbentuk bulat dan kemudian jaring yang terdapat pada saringan akan menjadi tempak menempelnya telur ikan komet. kemudian 
Setelah saringan ditebar kedalam akuarium, tahap selanjutnya adalah penebaran telur pada setiap perlakuan. Telur yang digunakan pada setiap perlakuan sebanyak 100 butir.

\section{Parameter Penelitian}

\section{Daya Tetas Telur}

Setelah penetasan terjadi maka dilakukan pengamatan untuk mengetahui daya tetas telur atau Hatching Rate. Upaya ini bertujuan untuk mengetahui jumlah telur yang menetas dari jumlah telur yang dihasilkan. Dihitung menggunakan rumus menurut (Nur et al dalam Pangkreksa, 2016) dengan rumus :

$$
\text { HR }=\frac{\text { Jumlah Telur Menetas }}{\text { Jumlah Telur Dibuahi }} \text { X100\% }
$$

Kualitas Air

Parameter kualitas air yang diamati meliputi suhu, $\mathrm{pH}, \mathrm{DO}, \mathrm{CO}^{2}, \mathrm{NH}_{3}$.

\section{Daya Tetas Telur Ikan Komet (C.auratus) \\ HASIL DAN PEMBAHASAN}

Berdasarkan hasil pengamatan terhadap daya tetas telur ikan komet yang diberi perlakuan berupa penggunaan suhu air yang berbeda pada proses penetasan diperoleh data yang disajikan dalam bentuk grafik pada Gambar 2.

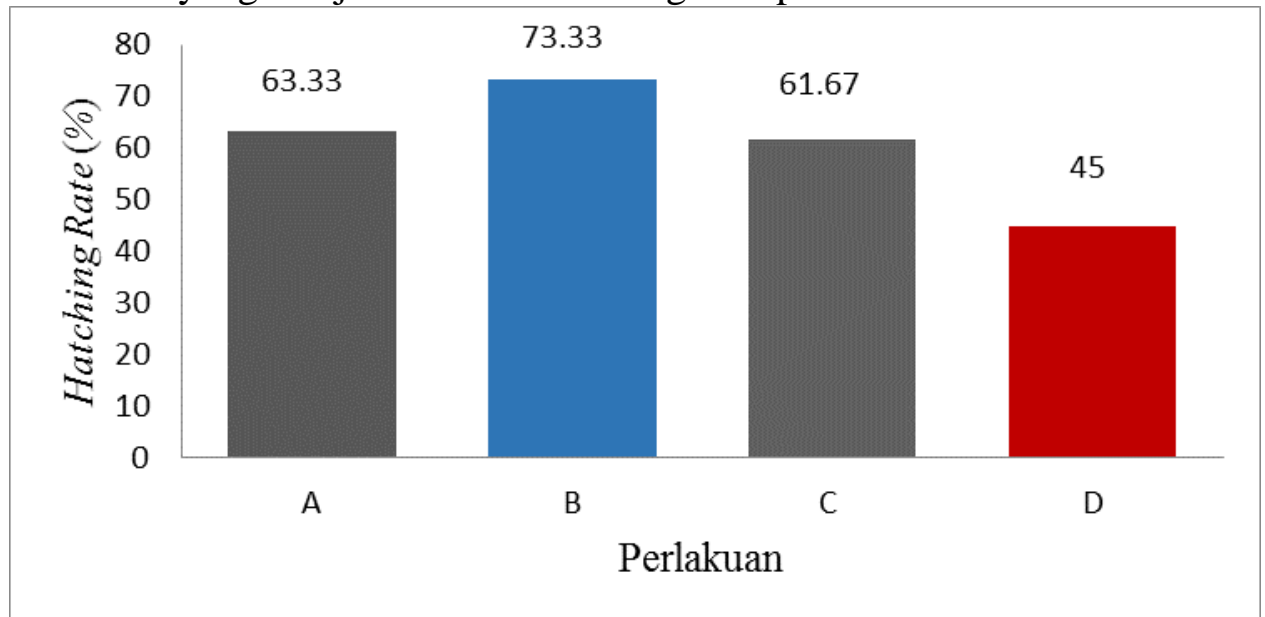

Gambar 2. Rata-rata daya tetas/Hatching Rate telur ikan kometyang ditetaskan pada air dengan suhu berbeda.

Data pada Gambar 3 menunjukan bahwa daya tetas telur ikan komet tertinggi terjadi pada perlakuan $\mathrm{B}$ (suhu $28^{\circ} \mathrm{C}$ ) yaitu sebesar $73,33 \%$, kemudian diikuti perlakuan $\mathrm{C}$ (suhu $30^{\circ} \mathrm{C}$ ) sebesar $61,67 \%$, selanjutnya perlakuan $\mathrm{A}$ (suhu $26^{\circ} \mathrm{C}$ ) sebesar $61,33 \%$, dan untuk daya tetas terendah terdapat pada perlakuan D (suhu $32^{\circ} \mathrm{C}$ ) yaitu sebesar $45 \%$. Data daya tetas telur yang diperoleh selanjutnya dianalisis dengan analisis sidik ragam pada taraf 5\%. Hasil analisis tersebut disajikan pada Tabel 3. 
Jurnal Akuakultur Sungai dan Danau Vol. 4 No. 1 Tahun 2019 Hal. 21 - 27

ISSN Print 2503-4766

ISSN Online 2597-8837

Tabel 1. Analisis sidik ragam pada taraf 5\% terhadap daya tetas telur ikan komet yang ditetaskan pada air dengan suhu berbeda.
PERLAKUAN
Derajat Tetas $(\%)$
Notasi

\begin{tabular}{ccc}
\hline A & 61.33 & $\mathrm{~A}$ \\
B & 73.33 & $\mathrm{~B}$ \\
C & 61.67 & $\mathrm{~A}$ \\
D & 45.00 & $\mathrm{C}$ \\
\hline
\end{tabular}

Keterangan : angka-angka yang diikuti oleh huruf kecil yang sama menunjukkan berbeda tidak nyata pada taraf $\alpha 5 \%$.

Berdasarkan hasil analisis sidik ragam pada taraf 5\% (Lampiran 3) menunjukkan bahwa penetasan telur dengan suhu air berbeda memberikan pengaruh yang berbeda nyata terhadap daya tetas telur ikan komet. Daya tetas telur terbaik pada penelitian ini terdapat pada perlakuan B yaitu sebesar $73.33 \%$ yang berbeda nyata dengan perlakuan A, C dan perlakuan D, sementara perlakuan A berbeda tidak nyata dengan perlakuan $\mathrm{C}$.

Tingginya daya tetas telur pada perlakuan B (suhu $28^{\circ} \mathrm{C}$ ) diduga merupakan suhu optimal pada proses penetasan telur ikan komet. Suhu optimal pada proses penetasan menyebabkan proses metabolisme berlangsung baik, sehingga perkembangan embrio akan berlangsung sempurna hingga telur menetas. Rendahnya daya tetas telur pada perlakuan A, C dan perlakuan D diduga karena suhu yang terlalu rendah dan terlalu tinggi menyebabkan perkembangan embrio menjadi tidak sempurna. Menurut Andriyanto et al, (2013) bahwa peningkatan suhu media inkubasi berbanding lurus dengan peningkatan daya tetas telur hingga mencapai suhu optimal. Jika suhu media terus meningkat melebihi suhu optimal maka daya tetas telur akan berangsur menurun. Proses penetasan telur akan terganggu pada suhu tinggi sehingga dapat menyebabkan kerusakan pada jaringan sel telur. Suhu yang sangat tinggi akan mempercepat laju penetasan telur sehingga telur tidak dapat melewati fase-fase penetasan telur dengan sempurna.

Ketidaksesuaian suhu dapat menyebabkankematian embrio terutama pada fase perkembangan embrio. Selanjutnya menurut Satyani dalam Nugraha et al, (2012) menyatakan bahwa suhu merupakan faktor penting dalam mempengaruhi proses perkembangan embrio dan daya tetas telur. Pada saat proses penetasan telur, suhu yang tinggi akan mempercepat metabolisme, sehingga perkembangan telur akan semakin cepat, tetapi dapat menghambat proses penetasan dan menyebabkan kematian. Sebaliknya suhu yang rendah membuat enzim (Chorion) tidak bekerja dengan baik pada kulit telur dan membuat embrio akan lama dalam melarutkan kulit, sehingga embrio akan menetas lebih lama.

\section{Kualitas Air}

Selama pelaksaan penelitian ini, terdapat beberapa parameter kualitas air yang diamati yaitu, Suhu, $\mathrm{pH}, \mathrm{DO}, \mathrm{CO}_{2}$ dan Ammonia. Dari hasil penelitian pengukuran parameter kualitas air selama penelitian dapat dilihat pada lampiran 10. Perlakuan suhu selama penelitian adalah $26^{\circ} \mathrm{C}$ (Perlakuan A), $28^{\circ} \mathrm{C}$ (Perlakuan 
B), $30^{\circ} \mathrm{C}$ (Perlakuan C), $32^{\circ} \mathrm{C}$ (Perlakuan D). Derajat keasaman (pH) selama penelitian adalah berkisar antara 7,30-7,70. Kandungan oksigen terlarut (DO) selama penelitian adalah berkisar antara 6,30-8,50 ppm, sedangkan kandungan amoniak selama penelitian adalah berkisar 0,0026-0,0490 ppm.

Didalam pelaksanaan penelitian ini digunakan pemanas (Heater) untuk mengatur suhu pada tiap-tiap perlakuan.Untuk perlakuan A suhu yang digunakan adalah $26^{\circ} \mathrm{C}$, perlakuan B $28^{\circ} \mathrm{C}$, perlakuan C $30^{\circ} \mathrm{C}$, dan perlakuan D $32^{\circ} \mathrm{C}$.

Derajat kesasaman $\mathrm{pH}$ selama penelitian adalah berkisar antara 7,30 sampai 7,70. Kisaran ini masih berada dalam kisaran yang mendukung untuk kehidupan ikan.Hal ini sesuai dengan Hadid et al (2014), yang menyatakan kisaran $\mathrm{pH}$ yang baik untuk penetasan telur adalah 6,9-9,0.

Kandungan oksigen terlarut dalam penelitian ini berkisar antara 6.30-8.50 $\mathrm{mg} / \mathrm{l}$. Oksigen terlarut selama penelitian masih dalam kisaran toleransi untuk penetasan telur. Menurut Effendi, (2003) kadar DO 1,0 - 5,0 mg/l ikan dapat bertahan hidup tetapi pertumbuhan terganggu, sedangkan kadar DO > 5,0 mg/l kadar DO yang disukai oleh semua organisme perairan.

Kandungan ammonia dalam penelitian ini berkisar 0,0026-0,0490 ppm. Kandungan ammonia selama penelitian masi dalam kisaran toleransi untuk penetasan telur. Menurut Wardoyo dalam Kalabora, (2010) bahwa batas toleransi amoniak dalam air berkisar antara $0.1-0.3 \mathrm{ppm}$.

\section{KESIMPULAN}

Berdasarkan hasil penelitian perbedaan suhu inkubasi terhadap daya tetas telur ikan komet dapat ditarik kesimpulan sebagai berikut :

1. Perbedaan suhu memberikan pengaruh yang nyata terhadap keberhasilan penetasan telur ikan komet (C. auratus)

2. Perlakuan suhu yang terbaik terhadap daya tetas telur ikan komet $(C$. auratus) adalah perlakuan B, dengan persentase penetasan sebesar $73.33 \%$ dengan lama waktu 45 jam.

Dalam penelitian ini disarankan untuk penetasan telur ikan komet $(C$. auratus) sebaiknya menggunakan suhu $28^{\circ} \mathrm{C}$ karena menghasilkan daya tetas telur sebesar $73.33 \%$.

\section{DAFTAR PUSTAKA}

Andriyanto, W., B. Slamet dan I. M. D. J. Ariawan. 2013. Perkembangan Embrio dan Rasio Penetasan Telur Ikan Kerapu Raja Sunu (Plectropomalaevis) pada Suhu Media Berbeda. Jurnal Ilmu dan Tekonologi Kelautan Tropis. 5 (1) : 192-207.

Effendi. H. 2003. Telaahan Kualitas Air: Bagi Pengelolaan Sumberdaya dan Lingkungan. Kanisius. Yogyakarta.

Fahrurrazi. 2013. Pengaruh Perbedaan Suhu Terhadap Daya Tetas (Hatching Rate) Telur Ikan Betok (Anabas testudeineus). Skripsi Universitas Batanghari. Fakultas Pertanian. 48.

Hadid, Y., M, Syaipudin., dan M, Amin. 2014. Pengaruh Salinitas Terhadap Daya Tetas Telur Ikan Baung (Hemibagrus Nemurus Blkr.). Jurnal Akuakultur Rawa Indonesia, 2(1) :78-92. 
Kalabora, D. M. 2010. Pengaruh Suhu Terhadap Kelangsungan Hidup Dan Pertumbuhan Larva Ikan Mas (Cyprinus Carpio). Berkala Perikanan Terubuk. ISSN 0126-6265. Vol 38 No.1. 71-81hal.

Nugraha, D., M. T, Suparjo dan Subiyanto. 2012. Pengaruh Perbedaan Suhu Terhadap Perkembangan Embrio, Daya Tetas Telur dan Kecepatan Penyerapan Kuning Telur Ikan Black Ghost (Apteronotus albifrons) Pada Skala Laboratorium. Journal Of Management Of Aquatic Resources. Volume 1. No 1. 1-6 hal.

Putri, D.A., Muslim., M. Fitriani. 2013. Persentase Penetasan Telur Ikan Betok (Anabas Testudineus) Dengan Suhu Inkubasi Yang Berbeda. Jurnal Akuakultur Rawa Indonesia 1(2): 184-191.

Septian, H., H, Hasan., dan Farida. 2017. Pemberian Pakan Alami Artemia, Chlorella Sp Dan Tubifex Sp Terhadap Pertumbuhan Dan Kelangsungan Hidup Larva Ikan Komet (Carassius Auratus). Jurnal Ruaya Vol. 5. No .2. 21-27 hal.

Saanin, H. 1968. Taksonomi dan Kunci Identifikasi Ikan I. dan II, Bina Cipta. Bogor.

Wahyuningtias, I., R, Diantar., O.Z. Arifin. 2015. Pengaruh Suhu Terhadap Perkembangan Telur Dan Larva Ikan Tambakan (Helostoma Temminckii). e-Jurnal Rekayasa dan Teknologi Budidaya Perairan. ISSN: 2302-3600. Volume IV No 1.440-448. 